\title{
Unity and Differentiation of Legal Regulation of Entrepreneurial Relations in the Civil Law
}

\author{
Ainur G. Demieva \\ Kazan (Volga Region) Federal University, Kremlevskaya str., 18, 420008 Kazan, Russia
}

\section{Doi:10.5901/mjss.2014.v5n24p480}

\begin{abstract}
In the context of unity and differentiation, the article touches upon principles of legal regulation in the civil law. The author shows that the studied principle is one of the basic ones in the system of mentioned principles. In terms of analysis of the principle, the article describes several tendencies of development of legal regulation of entrepreneurial relations in civil law. Dwelling on one of the most common types of entrepreneurial activity (commerce), the author shows several tendencies towards differentiation of legal regulation with entrepreneurial participation.
\end{abstract}

Keywords: legal regulation, principles of legal regulation, civil law, subject of legal regulation in civil law, unity and differentiation, tendencies towards unity and differentiation, legal relations with entrepreneurial participation.

Modern system of legal regulation in entrepreneurial activity has not yet developed into a complex system of norms and therefore may be characterized as a compilation of general provisions that lacks any variety and complexity of problems relevant entrepreneurial activity.

No doubt, that political processes taking place in modern Russia have certain influence on economy. This includes low efficiency of the financial system and mechanisms of inter-branch capital flow, lack of competitive market environment, inefficient credit and banking environment, high administrative barriers, low legal culture in Russia. All these factors add some specific qualities to the entrepreneur as a subject of this type of activity and its results [1].

It seems that some other countries with market economy tend to develop the market system rather than to substitute it with state economy and to debate on reasonable limits of the freedom of enterprise rather than to revoke this freedom [2].

The Russian economy making switch to market relations, significant changes in the theory of legal regulation of entrepreneurial relations came out. Meanwhile, it is obvious that at the moment the Russian doctrine has not given much place to the problem of unity and diversity of this type of relations yet. Besides, law enforcement practice in the field proves the necessity to give special attention to the topic.

Aiming at defining the role of unity and differentiation in legal regulation of entrepreneurial relations, it is essential that, first of all, we should consider legal regulation and its principles, find out peculiarities of entrepreneurial relations and their legal regulation in civil law. In general, legal regulation is a system of coherently organized legal measures aimed at systemizing social relations as well as complying with interests of legal subjects. It is well known that legal regulation, for having certain legal influence, helps to define specific rights and obligations of legal subjects.

Accordingly, legal regulation is a system based on specific principles. At the same time, these principles of legal regulations may not be associated with the principles of law. Despite the fact that principles of law reflect main peculiarities of legal regulation in any branch of law, principles of legal regulation are based on organization of the relevant legal data.

Among principles of legal regulation, we can define the following: principle of legality, principle of balance between private and public legal stimulation and restriction, principle of unity and differentiation. It should mentioned that the legal data needs systemizing. Therefore one of the basic principles of legal regulation is the principle of unity and differentiation. Besides, this principle accounts for dividing any branch of law into general and special parts, etc. Norms regulating a branch of law vary so much that a detailed differentiation is simply unavoidable.

It is evident, that legal regulation of entrepreneurial relations in civil law is also subject to these principles. It is the principle of unity and differentiation that, among other principles, reflects all peculiarities of legal regulation of entrepreneurial relations in its complex. On the other side, these relations influence greatly on the way this principle works. To define specifics of the principle of unity and differentiation of legal regulation of entrepreneurial relations in civil law, it is necessary to study these relations.

Dwelling on the entrepreneurial relations, we should firstly refer ourselves to the subject of legal regulation in civil 
law. Structurally based on Article 2 of the Civil Code of the Russian Federation (hereinafter referred to as the CC) [3], it features relations based on entrepreneurial activity. In fact, this Article is a normative prerequisite of the unity and differentiation of legal regulation of entrepreneurial relations and contains specific features of such relations.

The entrepreneurial relations are characterized of a special subject, object and subject-matter. The subject of this type of relations is a person legally registered as an entrepreneur, i.e. individual entrepreneur, a company. The main object of these relations is profit, i.e. the purpose of conducting entrepreneurial activity. The subject matter of entrepreneurial relations is mainly peculiar with their contractual nature.

It should be pointed out that entrepreneurial relations are generally inconsistent. However, they are consolidated by a unified basis - entrepreneurial activity. Accordingly, peculiarities of the relations under examination reside in the fact that their system is based on the principle of unity and differentiation. In this respect, legal regulation of these relations may be held only in complex, i.e. including public and private legal fundamentals. The same conclusion may be made in relation to legal regulation of these relations in civil law. This should be based on the same principles, at any rate on the fact that all relations in civil law have similar characteristics (mainly property, etc), as well as differential differences.

No doubt, the variety of legal relations in civil law doesn't exclude, but proves the fact, that all social relations comprised by the subject of civil law have one common feature. This feature of the civil law is the most important prerequisite justifying unity of legal regulation of all spheres of social life in civil law. As a criterion that allows to separate property relations viewed as a subject of civil law from property relations governed by different branches of law, the author underlines the value oriented character of the property relations.

Unity, as a term, denotes similarity, complete resemblance, cohesion, integrity, solidity and interconnection. Unity in law relates to internal and indissoluble connection of all norms governing relations that make a subject of legal regulation in a specific branch of law. In the meantime, the proof that internal differentiation takes places in the framework of unity rests on the fact that, apart from general norms, it contains some special norms applicable on different levels and in various spheres of social relations.

Under the current circumstances, the role of differentiation keeps. Differentiation (in French, differentiation - from the Latin word differentia - diversity, distinction), division of the whole into separate parts, forms and levels. Although lawmaker doesn't use this definition, differentiation has always been a characteristic feature of legal regulation.

The more developed the law, the more differentiated treatment to issues of social life it gives [4]. In fact, analysis of the recent changes in civil legislation in terms of the principle of unity and differentiation of legal regulation allows us to single out several tendencies of development of legal regulation of entrepreneurial relations. These tendencies prove that the studied principle of legal regulation has a fundamental character.

One of such tendencies is transformation of rules related to entrepreneurial activity into general norms of civil law. This tendency has become evident after adoption of the Conception of Civil Legislation of the Russian Federation [5]. For instance, since March 1st 2014 the main source of the civil law has become a custom with no indication to a sphere of its development and application instead of a custom of commerce [6]. We that the concept of a custom of commerce should be preserved as one of the types of customs.

When customs develop, behavior of participants in civil legal relations become essential. The important role in development of common norms is played by judicial and arbitral practice and non-governmental organizations activity in unofficial codification of such norms. Compilations of rules they make are applied if there is reference to them in an agreement.

One of the most significant codifications of the kind are International Rules for the Interpretation of Trade Terms, Incoterms, that are used in International Trade Law [7]. Special place in private legal unification is taken by UNIDRUA Principles of Universal Commercial Contracts [8,9].

Another example of development of general norms in civil law from special norms are new rules on resolutions of general meetings (see Article 8 of the CC). In order to settle a fair balance of interests between all members, these resolutions of general meetings (resolutions of corporate members, resolutions of property holders, resolutions of creditors in cases of bankruptcy, etc) are enlisted as legal facts that basically encourage development of rights and obligations.

One more recent tendency in development of legal regulation in civil law of the examined relations is development of degree of differentiation of legal regulation of entrepreneurial relations, as a result, creation of a new type of civil legal norms in the corresponding sphere. Thus, for instance, one of the innovations of a new law related to the institute of agency is introduction of irrevocable power of attorney (see Article 188.1 of the CC). In the meantime, it may be issued by a person conducting entrepreneurial activity.

Thus, transformations in governing economy bring about such economic situation when a more efficient legal form is inter-branch differentiation of legal regulation of entrepreneurial relations. At this point any differentiation of legal 
regulation should be conducted in terms of the rule permitting diversities, if they are justified, proved and pursue constitutionally approved aims, while applicable legal means relevant these aims fit them.

It is essential to determine basis of differentiation of legal regulation of entrepreneurial relations. Since defining prerequisites of differentiation of legal regulation may allow to find the basis, essence and aim of the civil legislation. Besides, it may help to avoid subjective and random differentiation of legal regulation of entrepreneurial relations.

We can disclose the prerequisites of differentiation of legal regulation on the following example. No doubt, that from the legal point of view entrepreneurial activity is a systematic contractual activity having private and public significance, as well as their fulfillment. In the meantime, it is know that the main type of contracts made by an entrepreneur to get profit is sale and purchase agreement. In terms of this agreement and in accord with the Civil Code of the Russian Federation (see Article 30), there can be defined separate types of contractual obligations.

Purchase and sale type of agreement (see Section 30 of the RFCC) can have several subdivisions according to their contractual obligations, which includes retail purchase, delivery of goods, including goods for state requirements, agricultural procurement contract, power supply service, real estate sale, business sale agreement. Besides, in order to provide single economic area in the Russian Federation by setting requirements for companies and maintaining commerce, there came out a new Federal Law from December 12, 2009 No 381-FL "About the Fundamentals of the State Control over Commerce in the Russian Federation" [10], etc. Accordingly, apart from general provisions, commerce in trade business is also legally governed by some special norms corresponding to public interests.

In terms of the unity of the subject of civil legal regulation we can single out relations in entrepreneurial activity. In the meantime, legislation in the related field may be differentiated not only on the basis of the regulated relations but public interest.

Summing it up, we can point out to the fact that legal regulation is a system of legal measures based on certain principles, including the principle of unity and differentiation as one of the most important. This principle helps to organize the existing legal data, dividing it to several parts (General Part, Special Part, etc). Besides, the principle of unity and differentiation is methodically significant. As it was stated before, it helps to find out a serious of tendencies to development of the civil legal regulation of entrepreneurial relations.

\section{References}

For more details, see the article of Perry Kanvar "Does culture impact on entrepreneurial activity?" Entrepreneurship, Key Topics Posted: November 8, 2010.

See, for instance, Department for Business, Enterprise and Regulatory Reform Act 2013. DateViews 20.03.14. URL: www.berr.gov.uk/files/file42362.pdf.

Civil Code of the Russian Federation. Part 1 from 30.11. 1994, No 51-FL // Corpus of Legislative Acts of the Russian Federation. 1994. No 32. P. 3301.

N. I. Matuzov, A. V. Malko. Theory of State and Law. M.: Urist, 2004. - P. 249.

Superior Commercial Code of the Russian Federation: Bulletin, No 11, November 2009.

Federal Law from 30.12.2012 No 302-\$3 "On Amendments to Chapter 1, 2, 3, 4 of Part 1 of the Civil Code of the Russian Federation" // Corpus of Legislative Acts of the Russian Federation from 31.12.2012. No 53 (Part I). - P. 7627.

Incoterms 2010. Publication No 715; Comments to the International Rules of Interpretation of Trade Terms INCOTERMS 2010 (edited by L. N. Galenskoi) - Sistema GARANT, 2011.

UNIDROIT Principles of International Commercial Contracts 2010. URL: http://www.unidroit.org/english/principles/contracts/ principles2010/blackletter201. O-english.pdf.; Principles on International Commercial Contracts UNIDRUA 2010 / Translated from A. S. Komarova. - M.: Statut, 2013. - P. 758;

Ramberg Ch. E-Commerce. UNIDROIT Principles: New Developments and Applications - 2005 Special Supplement ICC International Court of Arbitration Bulletin. ICC Publishing. 2005. P. 51-56.

Corpus of Legislative Acts of the Russian Federation from 04.01.2010, No 1. Art. 2. 